\title{
Machado de Assis e sua arte cênica
}

Sábato Magaldi

Osing INTERESSADOS em teatro e, em maior abrangência, na cultura brasileira só podem regozijar-se com a admirável pesquisa feita por João Roberto Faria e sua publicação do livro Machado de Assis do teatro: textos críticos e escritos diversos, pela Editora Perspectiva, reunindo os escritos de Machado de Assis sobre a arte cênica.

Nosso maior escritor é bem conhecido como romancista, contista e poeta, mas esta coletânea amplia de forma extraordinária a produção machadiana, atenta a um gênero por ele cultivado e cuja análise abre um período importante de vida cultural do país.

João Roberto Faria lembra que Machado "já estava com 31 anos de idade quando iniciou a publicação de seus volumes de contos e romances". Era conhecido antes, porém, "como folhetinista, crítico teatral, crítico literário, comediógrafo, poeta, tradutor - de poemas, peças teatrais e romances - e até mesmo como censor do Conservatório Dramático", órgão oficial incumbido de julgar os textos que seriam levados ao palco.

Essa ampla atividade foi suficiente para conferir-lhe o título de "nosso principal crítico literário e teatral da década de 60 do século xix". Exemplo desse juízo se encontra na "carta que lhe endereçou José de Alencar, em 1868, pedindo-lhe que opinasse sobre alguns poemas e o drama Gonzaga ou A Revolução de $M i$ nas, de Castro Alves". O autor menciona a enorme colaboração machadiana em periódicos como Marmota Flumi- nense, A Marmota ou O Espelho, Diário do Rio de Janeiro; ou mesmo O Futuro e Imprensa Acadêmica de São Paulo, além dos dezesseis pareceres emitidos para o Conservatório Dramático, entre 1862 e 1864. Afirma ele ainda, com razão, que os escritos teatrais machadianos "não revelam apenas uma individualidade; mais que isso, iluminam um dos períodos mais ricos da história do teatro brasileiro".

Há uma observação interessante de Machado, visível até algumas décadas passadas, quando o dramaturgo brasileiro passou a desfrutar de maior espaço no repertório das nossas companhias: "não tínhamos teatro dramático, o que tínhamos era uma inundação de peças francesas, um excesso de traduções 'enervando' a nossa cena". De quem a culpa desse estado de coisas? A seu ver, "dos empresários dramáticos, que preferiam encenar traduções a animar os autores nacionais". Passaram-se muitas décadas para que se firmasse uma dramaturgia brasileira, até que a televisão se tornou mais convidativa para os nossos valores.

Outro importante conceito de Machado, evocado por João Roberto Faria: "A leitora sabe que o clássico não é o meu forte; aplaudo-lhe os traços bons, mas não o aceito como forma útil ao século. Digo forma útil, porque eu tenho a inqualificável monomania de não tomar a arte pela arte, mas a arte, como a toma Hugo, missão social, missão nacional e missão humana".

Tinha Machado a plena consciência de que o teatro não é uma "indústria" e que "o governo devia ter, sim, uma res- 
ponsabilidade em relação à arte". Esse conceito foi respeitado até na odiosa ditadura e acabou por ser violentamente destruído no melancólico neoliberalismo, cuja preocupação verdadeira é apenas a de beneficiar a fortuna. Não se pode omitir, porém, uma passagem do livro, em que Machado, julgando uma peça que trazia à cena o tema da escravidão, teria mostrado "preconceito social" e agido "francamente com a sociedade intolerante de sua época", conforme o comentário de Eugênio Gomes a um parecer dado pelo escritor na condição de censor do Conservatório Dramático.

Abraçava Machado uma idéia que o neoliberalismo aboliu: "O Estado, que sustenta uma academia de pintura, arquitetura e estatuária, não achará razão plausível para eximir-se de criar uma academia dramática". Lembre-se de que foram extintos o Serviço Nacional de Teatro e a Comissão Estadual de Teatro do Governo de São Paulo, cujo apoio assegurou tantas iniciativas importantes para o palco.

Observa o autor, com razão, que "Machado não valoriza as peças pelo conteúdo, mas pela forma". Para um estilista primoroso, não poderia ser outro o conceito, mas o conteúdo não me parece nunca postergado. Escreve Machado: "Eu não creio nos intuitos moralizadores do teatro, nem penso que Tartufo matasse a hipocrisia". Ponto de vista de absoluta procedência.

Machado, segundo João Roberto Faria, "jamais aceitou os recursos do chamado baixo-cômico, que lhe pareceram sempre de mau gosto". Por isso, certamente, a ausência de Martins Pena no "balanço" que fez do teatro brasileiro de seu tempo. Sem dúvida, "um preconceito típico da época em que escreveu

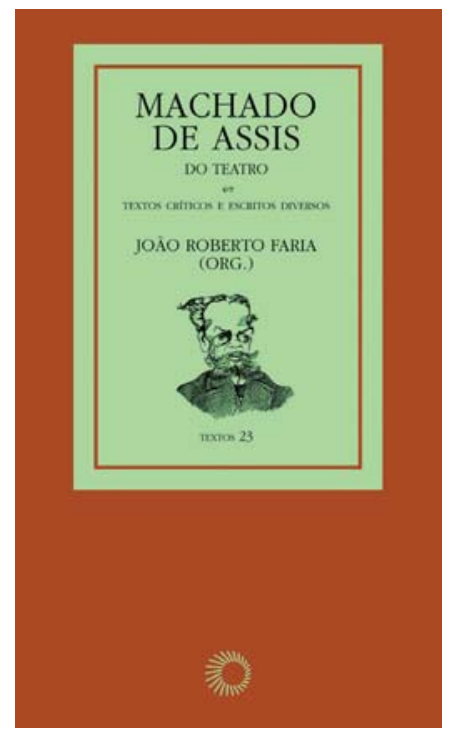

FARIA, João Roberto. Machado de Assis do teatro: textos críticos e escritos diversos. São Paulo: Perspectiva, 2008. 679p.

sobre teatro". Argumenta o autor: "Ao equívoco de deixar de lado as comédias de Pena somou-se mais um: o de considerar Gonçalves de Magalhães isoladamente como o fundador do teatro brasileiro. A historiografia posterior corrigiu essa injustiça e recolocou Martins Pena em seu devido lugar". Talvez seja esse o equívoco único atribuível a Machado de Assis.

Sábato Magaldi é crítico, historidor e professor de teatro. Deu aulas na Sorbonne (Universidade de Paris III) e na Universidade de Aix-en-Provence. Em julho de 1995, tomou posse na Academia Brasileira de Letras. É autor de vários livros, entre eles Panorama do teatro brasileiro, Iniciação ao teatro, Nelson Rodrigues: dramaturgia e encenação e $O$ texto no teatro. @ - vansteen@uol.com.br 